\title{
Local Economic Development: A Test for Relevance in South Africa
}

\author{
Sebeka Richard Plaatjie \\ Department of Development Studies, University of South Africa, South Africa \\ plaatsr@unisa.ac.za
}

\begin{abstract}
The contemporary discourse on local economic development (LED) has gained widespread popularity in the political, intellectual, and public social arenas of development issues. It has become a "new," glittering philosophy for development. Through the persuasive use of romanticism, LED has managed to achieve moral high ground in development, although it has since been confronted by unresolved theoretical and ideological tensions. The challenges facing LED are (1) the meaning of "local" in LED in a "globalized" world (2) the meaning of "development" in LED in a democratic, multicultural and racialized class society like South Africa, and (3) the explanation and moral justification as to what this "development" is, or whom it should be aimed at, in a society with such a grotesquely racialized "past". By drawing on the findings from a recent study of LED within the Ekurhuleni Aerotropolis project, in South Africa, we provide a critique of LED. We highlight its illusive philosophical foundations and their underlying mischief in South Africa. We argue that unless the said tensions are resolved, LED discourse will remain a rhetorical ploy for legitimating underdevelopment for blacks, and a methodical device to entrench the racialized socio-economic evils of apartheid in South Africa.
\end{abstract}

Keywords: Local economic development, development, race, inequality, South Africa.

\section{Introduction}

The idea of local economic development (LED) is generally reified across both the political and intellectual community to be the panacea for contemporary development challenges in South Africa. Very seldom will any political and intellectual discussion about development or poverty alleviation fail to reference LED as a solution, yet LED is embroiled in unresolved theoretical and ideological tensions and contradictions that nullify its every essence. The question is therefore why, or rather, how does the mainstream LED narrative manage to survive the critique from its exteriority, which suggests it is part of the civilising mission and which rejects it ipso facto? And how does LED manage to overcome fiercely competing ideological tensions and contradictions within itself for example, critics of the exteriority of mainstream LED thinking, following post-development critiques, suggest that the LED discourse is entrapped within the western-centric conception of "development" (Pieterse, 2000). This criticism is echoed by scholars using traditions such as dependency, Marxism and de-coloniality (Amin 1974, 1997, 2011; Dussel, 1998; Grosfoguel, 2011). These scholars elevate their analysis to world systems and argue against the parasitic global political-economic relations which favor the wealthy European nations. They also argue against the Euro-American-centric epistemic foundation of the development enterprise and reject it for its complicity with neo-colonialism and colonialists (Amin 1974, 1997, 2011; Bergesen and Wallerstein, 1983; Dussel, 1998, 2002; Escobar, 2004; Grosfoguel, 2011; Hopkins and Wallerstein, 1980). The intention of this essay is not to concern itself so much with the critiques against LED arising from its exteriority as listed above, as we deal with this elsewhere. Instead, the objective of this essay is to theoretically test the fitness of purpose of LED theory and practice in resolving development challenges.

That is, to critically examine the efficacy of what LED theory and practice claim it is capable of doing, and/or is currently doing in order to overturn the development challenges of poverty and inequality in South Africa. This exercise will be particularly important because it will illuminate, and seek to engender some of the fundamental historical problems of development, such as the problem of race, which remains kept outside, and unaccounted for in mainstream LED thinking and practice in South Africa. Furthermore, the essay will explore newer ideological possibilities that will need mainstreaming into LED in order to achieve a transformative LED regime appropriate to the development challenges in South Africa. It is our view therefore that failure to achieve a transformative LED regime able to address the race problem in South Africa, will only entrench the racialized socio-economic evils of apartheid. This essay is a theoretical study that is both descriptive and explorative. Documentary sources such as government documents, journal articles, and books were utilised as primary data, for both data collection and analysis. In the first section of 
the essay, we reflect briefly on the hegemonic conceptions of what LED is, or, is about. Such an exercise establishes a clearer conceptual frame of the dominant conception/s or ideas about LED. In doing this, we uncover the ideological frame from which South Africa's LED theory and practice were to be conceived after 1994.

Building upon the said catalogue of conceptual frames, we progress to demonstrate the centrality of LED thinking in the psyche of mainstream development discourse in South Africa, including how it is understood and practised. Here, we also demonstrate how LED's internal ideological tensions and contradictions are inherited from the economic ideological tensions of the late 1990s, including the Reconstruction and Development Programme (RDP), and the Growth, Employment and Redistribution (GEAR) programme, and other articulations. The second part of the essay provides some critical reflections. These reflections are based on the critical analysis of mainstream LED thinking and practice in South Africa, and its dynamic complexities related to the problem/s of development on the ground. This section is then followed by concluding remarks.

\section{Defining Local Economic Development}

Lodged within LED discourse itself, are internal ideological and methodological tensions. According to LED academic literature, these tensions are mainly the tussle between the pro-poor and pro-market approaches (Bond, 2003; Nel and Binns, 2003; Nel and Rogerson, 2016) more particularly in the context of South Africa. It is against this background of the said unresolved ideological tension, including contestations within LED discourse, that Nel and Rogerson (2016) have opined that LED has become victim to a lack of consensus about its own meaning. For example, The World Bank (2016) defines LED as follows: "The purpose of local economic development is to build up the economic capacity of a local area to improve its economic future and the quality of life for all. It is a process by which the public, business and non-governmental sector partners work collectively to create better conditions for economic growth and employment generation". For the Local Government Turnaround Strategy (RSA, 2009), LED refers to the approach a municipality and region may take to encourage investment by big business, small local business development, tourist industries or large sector economic management in mining, manufacturing or farming. Blackely and Leigh (2010) advance that LED strives for the preservation of an increase in the standard of living through human physical development based on the principles of equity.

For Rodriguez-Pose and Tijmstra (2005, 3), LED only refers to "those development strategies that are territorially-based, locally owned and managed, and which are aimed at increasing employment and economic growth". According to Bartik (cited in Rogerson 2009, 2003), LED represents “...local economy's capacity to create wealth for residents". Helmsing and Egziabher $(2005,1)$ think of LED as a partnership between local government, NGOs, community-based groups and the private sector, that manages existing resources to create jobs and stimulate the economy of a well-defined territory. It is clear from these definitions that while there are some ideological similarities in various LED conceptions, there are elements within these definitions that are also conceptually antithetical to one another. For example, contestations over whether LED is a poverty relief or an enterprise/business development initiative, or even a spatial or industry/sector-based phenomenon, always crop up. Notwithstanding, Mqedlana (2014), attempting to make sense of these varied definitions, found LED to have been understood at least in four different ways, namely as a process; an economic development intervention; a locality and geographically-based development intervention; or a collaboration of key stakeholders. However, as much as Mqedlana's (2014) observation is useful, his categories are imbued with intrinsic ideological tensions owed to LED's fuzzy frame. For example, if LED is a geographical and a spatially-based development intervention, then what are spatial parameters of inclusion and exclusion in a globalised world?

Furthermore, focusing on South Africa, what would be the most plausible spatial demarcations of inclusion and exclusion in such a racially designed country? In addition, such ideological tensions make themselves known at the level of methodology. That is, the tension about which of the two methods -the pro-poor or promarket, is the best suited and most efficient to achieve development? However, what is more important to mention at this stage is that in South Africa, LED is understood and practised through a myriad of untidy processes of various forms across all municipalities. Often, these forms not only produce clashes between the 
pro-poor and pro-growth models, but sometimes also contradictions in their outcomes, and between policy and practice. For example, Mayekiso, Miller, and Swilling (2000) note the corporate bias of LED practice in South Africa in general, with Rogerson (2005) pointing out that pro-poor LED models are more deeply entrenched in policy than in practice. Ekurhuleni, more than other metropolitan municipalities, is said to represent the most advanced pro-poor LED agenda from a policy perspective under the theme of a "peoplecentred economy" (Rogerson, 2005). We reflect on these issues in some detail later on in the essay. Notwithstanding these ideological tensions and contestations stemming from the conceptual fuzziness of LED, it remains government's apex panacea for development challenges in South Africa.

The centrality of LED discourse in the psyche of the South African government and the belief in its potential to tackle poverty challenges are beyond question. This commitment is particularly evidenced by the entrenchment of LED by government, through several pieces of legislation, such as Sections 151 and 152 of the Constitution of the Republic of South Africa (RSA, 1996), as well as the Municipal Structures Acts, 117 of 1998 (RSA, 1998a), and the White Paper on Local Government (RSA, 1998b). To bolster LED, the White Paper on Local Government (RSA, 1998b), dictates the moral code of developmental local government to LED discourse in South Africa (Nel and Rogerson, 2016). The latter code is defined as the local government committed to working with citizens and groups within the "community" to find sustainable ways to meet their social, economic and material needs, and to improve their quality of life. We also observe how in furtherance of LED thinking government introduced several programmes and guidelines specifically aimed at advancing LED practice, such as the National Spatial Development Perspective (NSDP). The NSDP states that its principles and methodology should inform the development plans, policies and programmes of all spheres and agencies of government as a matter of policy (The Presidency, 2006, cited in Rogerson, 2008 and Oranje et al., 2009).

Mohammed (2006 cited in Rogerson, 2008) states that the NSDP insists on government spending on fixed investment that must be concentrated in areas/localities with economic growth potential. Government's commitment to LED is clearly reflected in the Integrated Development Plan (IDP). This plan in accordance with Section 34 of the Municipal System Act 2000 (RSA, 2000), requires of all municipalities to conduct annual reviews and amend their IDPs to suit changing demands. Most importantly, it forces them to engage with LED policy (Gunter, 2005). This was further entrenched in the 2006-2011 and revised 2012-2016 National LED framework, and more recently, in the National Development Plan (NDP). This provides proof of steadfast support for LED through legislation, guidelines and political support, thereby solidifying LED as a serious pillar in South Africa's development discourse. However, it must be noted that the foregoing efforts to bolster LED must be read against the backdrop of neoliberalist, depoliticised development - the anti-politics machine, to borrow from Ferguson (1990), and its "moral" justifications for creating a "free" and "fair" enterprise for "all" in an otherwise very unequal and unfair South Africa. We now turn to reflect on the theoretical and philosophical understanding and practice of LED in South Africa.

\section{LED in South Africa: The Philosophy}

It is our view that, given the nature of the politics of concessions championed by the African National Congress (ANC) leading up to the democratisation of South Africa, the hegemonic Euro-American-centric ideological order/s and practices were followed. This is poignantly demonstrated in former President Thabo Mbeki's declaration that "Just call me a Thatcherite," (Poplak, 2015) after he had committed South Africa's macroeconomic strategy to the neoliberal economic order of the West. Mbeki's government shifted South Africa away from the RDP paradigm that was popular across communities. RDP was the mobilisation trope securing the ANC victory in the 1994 elections. He steered the macroeconomic policy in favour of GEAR, an unpopular move that almost leads to a split in the Tripartite Alliance in 2002 (Matjila, 2010; Pillay, 2006; Van Rooyen, 2012). It is our claim that the RDP was ideologically antithetical to the neoliberal economic policies of the West, and that it resonated greatly with the socialist principles in the ideology of the Freedom Charter. The RDP animated the sustainable livelihoods framework, which understands development to be a community participatory process that builds from below, and which privileges support for human capabilities above corporate enterprises (Hindson and Vicente-Hindson, 2005). 
GEAR was more consistent with Thatcherite, neoliberal, economic growth-obsession that favours austerity and deregulation. For Van Rooyen (2012), this policy shift would be a turning point in the development policy framework and the development discourse in post-apartheid South Africa. In terms of performance, Van Rooyen (2012) states that GEAR failed to achieve its objectives, except for reducing the budget deficit and regulating inflation. She insists that instead of the projected $6 \%$, the GDP growth rate was $2.9 \%$ per annum between 1994 and 2004. She adds that unemployment increased to 45\%, while private sector investment fell from $25 \%$ of the GDP in the early 1980 s, to $16 \%$ in 2004 . Moreover, poverty deepened, inequality widened and the number of people living on less than a dollar a day doubled. The period 2006 to 2011 yielded some improvements with regard to reducing poverty and hunger (Mbatha, 2014; Paton, 2014), but what thwarts GEAR's trickle-down theory is the fact that much of this economic growth was jobless. For Mbatha (2014), the relative success during the 2006-2011 periods in reducing poverty and hunger was due to the social income grants, which, by 2012, was already a source of livelihood for 16.6 million poor people in South Africa.

However, Mbatha (2014) also warns that, notwithstanding the improved poverty and hunger statistics, the gap between the poor and the rich has not improved. The ideological struggle around LED, namely the popular people-centred and redistributive development practice espoused by the RDP, on the one hand and the technocratic, growth-led approach of GEAR, on the other hand undergirds the contemporary idea and model of LED. We must note that the power balance, at least in practice, currently favours the pro-growth form. That is a development shrewdly dependent on the neoliberal logic of the "free" enterprise and economic growth, and the trickle-down hypothesis. This flies in the face of racialized inequalities and poverty generated systematically over centuries through colonialism, apartheid and racial capitalism against the black majority - a reality that continues well into present-day South Africa (Biko, 1978; Magubane, 1972; Terblanche, 2002). These racialized inequalities continue to favour whites and the emergent "black middle class" who gain more from the "free" enterprise and current economic growth regime of LED. We now turn to reflect on the fitness of purpose of LED in the context of the ensuing racialized problem of poverty and inequality in South Africa.

LED and the Test for Fitness in South Africa: It is worth noting that as much as LED came about in the global north and global south for slightly different reasons (Nel, 2001) its practice in both regions is also different (Pike, Rodriguez-Pose and Tomaney, 2016). In the global north, LED is focused on heavy investment, big business support and large projects (Nel, 2001; Nel and Rogerson, 2016). In the global south, however, the practice is predominantly dependent on the informal survivalist type, small-scale and community-based initiatives that have very little interest in participating in the global economy (Nel, 2001). Interestingly, in South Africa we observe LED practices where, to varying degrees, the informal sector, small-micro and medium-sized enterprises, and big business all at the same time champion it (Bond, 2003; Mbeba, 2014; Patterson, 2008). For example, the Dupe Trade Port project around the King Shaka airport in the eThekwini Municipality, and the recently launched Aerotropolis project in the Ekurhuleni Metropolitan Municipality are examples of mega LED projects in urban municipalities (City of Ekurhuleni Report, 2013; Gauteng Provincial Government and Ekurhuleni Metro Municipality, 2013; Houghton, 2016). Furthermore, existing particularly within rural areas of South Africa (former Bantustans), we have LED projects that do not go beyond the micro-scale of localized skills development, job creation and business support programs (Houghton, 2016).

While these LED forms are said to reflect the "natural" imbalances of the economic potential of the rural and urban areas, we are of the view that these LED forms are underscored chiefly by race, rather than the ruralurban divide. This is particularly evident in the conspicuous racialized distribution of LED forms, with the informal and survivalist type business entities being more prolific in black areas and more formal business enterprises being overly represented in white areas. This even both black and former white areas fall under the same municipal administration in both rural and urban areas. In this regard White (2002) aptly suggests that development is a racial project. Moreover, black hardship, exclusion and underdevelopment transcend rural and urban divides. Given South Africa's history of apartheid and racial capitalism, the LED practices in rural areas and townships vis-à-vis white areas thrive in spaces once designed to produce racial inequalities. The creation of Bantustans (for blacks), townships and white suburbs by the apartheid government's separate development doctrine, racially fragmented people into spatial enclaves of unequal distribution of wealth, opportunity, infrastructural support and development. It is under such a radicalised spatial design that we remember Fanon's Wretched of the Earth, where he speaks of the zone-of-being and the zone-ofnonbeing. 
"The zone where the natives live is not complementary to the zone inhabited by [the] white settler. The two zones are opposed, but not in service of a higher unity....they both follow the principle or reciprocal exclusivity. The settlers' town is [a] strongly-built town, all made of stone and steel. It is [a] brightly-lit town, all covered with asphalt. The town belonging to the colonised people... the native town. The reservation is a place of ill-fame. It is a world without spaciousness; men live there on top of each other, and their huts are built one on top of each other. The native town is a hungry town, starved of bread, of meat, of shoes, of coal, of lights" (Fanon 1961, 38-39).

Much of the colonial racial spatial design Fanon spoke of remains largely unchanged in South Africa. Mbeki's (1998) two nation state address in the National Assembly also confirms this point and suggests that the end of apartheid and the transition to democratic rule did not come with much socioeconomic transformation for the majority of black people. The rural areas or rural municipalities - former Bantustans - continue to be largely black and are still grossly underdeveloped and struggling with poverty twenty plus years after the new "democratic" dispensation. It is in rural municipalities and in small towns of South Africa in particular, where LED is understood more like a local government-led intervention in which poverty relief projects are prioritised (Nel and Rogerson, 2016). It is also rural municipalities in particular that experience the worst forms of disruption of community livelihoods and exploitation through LED, especially under the guise of tourism-led LED (Plaatjie, 2014). As we have commented elsewhere, it is our view that even when there could be potential for rural municipalities to benefit from tourism or tourism-led LED such potential gains to come at exceptionally high costs, and are often counterproductive to the thriving of the affected communities. We have noted elsewhere how in the name of tourism-led LED, poor rural communities such as the Khomanani San in the South African part of the Kgalagadi Transfrontier Park have been forcibly displaced from their land, their sources of food security and their places of worship. In short, their livelihoods have been interrupted to accommodate the tourism industry (Plaatjie, 2014). What is certainly interesting to note though, is how the legacy of apartheid still plays out through LED, or how LED animates apartheid. For example, the informal and semi-formal, and survivalist type enterprises in townships, because of their informality, do not enjoy much official government support.

However, the formal industry and business enterprises and SMME in formerly white areas and cities, enjoy greater official government support, and leverage more from better infrastructure in those areas. These racialized spatial inequalities and their skewed potential and capacities to respond to opportunities and vulnerabilities (Marais, 2016; Pike, et al., 2016) confront LED practice in South Africa, but remain unaddressed. As White (2002) would suggest, LED discourse has successfully hidden the racial character of the problem of development behind disembodied categories such as the "poor" or "communities" or even behind neutral concepts such LED itself. This serves to avoid confronting the source of the problem of race in development. The overemphasis of philosophies of the "free" market and a "class" struggle is further obfuscation of race as the central problem in development and LED discourse. It comes as no surprise that rural municipalities and township communities in urban municipalities in particular (all of which are black), do not gain much from major state-led LED projects. Instead, they are excluded from participating in these projects, as our study found to have been the case with the Ekurhuleni Aerotropolis Project.

Confirming our observation about the general exclusion and neglect of the township poor in mega LED initiatives, Ndabeni, Rogerson and Booysens (2016) state that research on innovative local economic development (ILED), focuses on the formal sectors, thereby rendering townships' informal sector and rural areas and communities' peripheral in studies of South Africa's innovative capacity. It is in this respect that Lorentzen (2011 in Ndabeni et al., 2016) observes that the poor black majority hardly features in innovation debates in post-apartheid South Africa. Furthermore, in a study of LED initiatives in six secondary cities of South Africa, Marais (2016) finds that even when there is evidence of the private sector in these cities playing a regional role through job creation via the expansion of the retail sector to the rural hinterlands, government is still reluctant to build on those initiatives. Marais (2016) states that none of the cities in the study considered maintenance of access routes important and that this in turn stifles the economic activity that could potentially reach the rural hinterland. Notwithstanding the said stark historical challenge of racialized poverty and inequality that is widely spread across all spheres of life in South Africa, the question of race remains curiously absent in mainstream LED thinking in South Africa. 
This absence remains to this day, and it is still unaccounted for, both politically and intellectually, except through populist political rhetoric and platitudes. Race mainstreaming, especially in LED, remains a bogey analytic category across government and the intellectual community, and more so in the development enterprise in general (Kalpana 2017; Kothari, 2006a; 2006b; White, 2002). That LED thinking and practice in a country with such a grotesquely racialist past shies away from confronting this singular, foundational, historical challenge of development, is a curious contradiction in the purpose of LED. It is our opinion that the negation of the racial question in LED discourse, particularly in South Africa, is either a result of the worst form of misdiagnosis of the problem, or, is a product of bad-faith and sinister motives. Such negation is a raceneutral/neutralising obfuscation of the central problem of race in the distribution of poverty and inequality. In simple terms, we argue that LED thinking, by eliding and disavowing the foundational problem of race in development, detracts from addressing the true problem of development in South Africa. This is the failure or the dishonesty of LED discourse in South Africa, namely to be unresponsive to the questions of who and the where of LED. It is a failure to decisively identify who ought to be the beneficiaries of LED support programs in a racially unequal South Africa.

Moreover, the failure to decisively identify the spatial locations targeted for LED support means that its resultant planning will not give dedicated support to particular beneficiaries to thrive in their respective, spatial locations and in their choice of development enterprises. It is our view that by attending to these issues, LED thinking will have gone beyond the disembodied categories and will be able to begin confronting the problems of development in South Africa head-on. Precisely because LED discourse does not confront race in development or act on it decisively, it has weak theoretical and methodical clout, poor legitimacy and suspects ethical grounding. We further hold that the absence of any concerted effort to systematically confront the race problem in development will continually exacerbate racial inequalities. The most privileged spaces of the urban centres, which are often occupied by whites, would be the biggest beneficiaries of LED opportunities and thus, exacerbate both race and "class" inequalities to unprecedented heights, as is already the case (Pike et al., 2016).

It comes as no surprise that the poverty trend survey in South Africa showed that black African households account for the vast majority of poor households, at $93.2 \%$ in 2006, with a slight increase to $93.7 \%$ in 2009 and 93,9\% in 2011 (Statistics South Africa, 2014). There are many intersecting factors undergirding racial inequalities and poverty in South Africa, but we contend that a typical catalyst for exacerbating these inequalities is the NSDP. This is because the NSDP declares that government spending on fixed investment should be concentrated in areas with economic growth potential. This further suggests that rural municipalities and townships in particular, more so rural municipalities, because of their poor infrastructure and sluggish economic activity, stand no chance in receiving any major infrastructure investment support from national government to unlock their economies. Marais (2016), commenting on LED strategies in secondary cities, affirms our observation and opines that South African secondary cities stand no chance to emerge as the winners when competing with metropolitan areas. We also note that LED planning in South Africa is increasingly gravitating towards regional or region-wide planning, with the Gauteng City Region (GCR) being a typical local example of an international trend. We believe the Regional Local Economic Development (R-LED) phenomenon is a step in the right direction.

This is particularly so, given the potential economic spinoffs of region-wide LED projects such as export processing zones, free ports and science and technology parks in urban areas spreading or spilling over into their hinterlands (Pike et al., 2016; Mansson, 2014). However, it is our view, notwithstanding the good intentions of regionalist planning, that R-LED in South Africa will suffer the fate of LED, unless it applies itself systematically through the prism of race, and dedicates itself to reverse the problem of racialized poverty and inequality. It is against this background of the neglected race question in development that we argue that the current regime of a LED thinking and practice in South Africa is emphatically incapable of providing lasting solutions to the country's prevailing challenge of development. It is on this score, that we also hold that meaningful LED discourse for South Africa is one that would face up to its historical challenges in the present situation. We argue that a more progressive and transformative LED in South Africa will demand a radically different approach that will also require race mainstreaming in LED discourse. And amongst the first things that this race-conscious LED paradigm should concern itself with, is for whose benefit and where these efforts must be focussed (Pike et al., 2016). 


\section{Conclusion}

Despite the centrality of LED in mainstream development thinking across the political and intellectual community in South Africa, this discourse has serious ideological and moral challenges. As we have already made clear, these challenges manifest more visibly, racially, with blacks being the poorest, regardless of where they find themselves, whether in the rural or urban areas, and whites enjoying the privileged side of the racial divide. Therefore, we believe that by virtue of the historical racialized character of development in South Africa, which continues to this day, mainstreaming of race in LED and in development discourse in general is of paramount necessity in South Africa, in particular. It is against this pressing challenge of the neglected race question in LED and development that we believe the current race-neutral regime of LED discourse is agonisingly unresponsive to the racial temperature of the development problem in South Africa. It is our view that the continued failure by LED and development to attend to the foregoing concern of the race problem in development is a gross dereliction of purpose for transformative development. More so, it is an exercise in bad faith, which only serves to entrench racialized poverty, inequality and underdevelopment. This renders LED unfit for purpose to deal with the development challenges of South Africa. Spatial Keynesianism or racial-spatial Keynesianism is proposed as frames of reference to prioritize preferential infrastructural support for black townships and rural areas as a matter of policy in order to unlock their potential as effective players in mainstream economic activities in South Africa.

\section{References}

Abrahamsen, R. (2000). Disciplining democracy: Development discourse and good governance in Africa. London: Zed Books.

Amin, S. (1974). Accumulation on a world scale: A critique of the theory of underdevelopment. Sussex: Harvester Press.

Amin, S. (1997). Capitalism in the age of globalisation: The management of contemporary society. London and New Jersey: Zed Books.

Amin, S. (2011). Ending the crisis of capitalism or ending capitalism? Daka: Pambazuka Press.

Bartik, T. J. (2003). Local economic development policy, In C. M. Rogerson, Strategic review of local economic development in South Africa. Draft final report submitted to Minister Sicelo Shiceka (dplg). Pretoria: German Agency for Development Cooperation (GTZ).

Bergesen, A. \& Wallerstein, I. (1983). Crisis in the world-system. London: Sage.

Biko, S. (1978). I write what I like: Selected Writings. Chicago: University of Chicago Press.

Blackely, E. J. \& Leigh, N. G. (2010). Planning local economic development: Theory and practice. (4th ed). Thousand Oaks, CA: Sage.

Bond, P. (2003). Debates in local economic development policy and practice. Urban Forum, 14 (2), 147-164.

City of Ekurhuleni. (2013). Special Aerotropolis Publication: essential special publication. Johannesburg: EMM.

Department of Provincial and Local Government (DPLG). (2006). National framework for local economic development in South Africa (2006-2011). Cape Town: RSA.

Dussel, E. (1985). Philosophy of liberation. New York: Orbis Books.

Dussel, E. (1998). Beyond Eurocentrism: The world-system and the limits of modernity, in. In F. J. Miyoshi, (ed), The culture of globalization. Durham, NC: Duke University Press, 3-31.

Dussel, E. (2002). World system and "trans"-modernity. Nepantla: Views from South, 3(2), 221-244.

Escobar, A. (2004). Beyond the Third World: Imperial globality, global coloniality, and anti-globalization social movements. Third World Quarterly, 25, 207-230.

Fanon, F. (1961). The wretched of the earth. New York: Groove Press.

Ferguson, J. (1990). The anti-politics machine: "Development," politicization, and bureaucratic power in Lesotho. Cambridge: Cambridge University Press.

Gauteng Provincial Government and Ekurhuleni Metro Municipality. (2013). Airport cities - World conference and exhibition: Ekurhuleni Aerotropolis Master Plan. Johannesburg; EMM.

Grosfoguel, R. (2011). Decolonizing post-colonial studies and paradigms of political economy: Transmodernity, decolonial thinking, and global coloniality. Journal of Peripheral Cultural Production of the Luso-Hispanic World, 1, 1-38. 
Gunter, A. (2005). Integrated development plans and local economic development. Africa Insight, 35(4), 3238.

Helmsing, A. H. J. (2001). Local economic development in Africa: New generations of actors, policies and instruments. Working paper No. 12. Regional and Local Development Studies. Addis Ababa: Addis Ababa University.

Helmsing, A. H. J. \& Egziabher, T. G. (2005). Local economic development in Africa: Introducing the issues, In Egziabher, T. G. \& A. H. J. Helmsing, AHJ. Local economic development in Africa: Enterprises, communities and local development. Maastricht: Shaker Publishing.

Hindson, D. \& Vicente-Hindson, V. (2005). Whither LED in South Africa? A commentary on the policy guidelines for implementing local economic development in South Africa. Conference paper prepared for the Eastern Cape Socio-Economic Consultative Council (ECSECC), July 2005. Eastern Cape: South Africa.

Hopkins, T. K. \& Wallerstein, I. (1980). Processes of the world-system. London: Sage.

Houghton, J. (2016). Regional and local economic development themes in contemporary South African cities. Local Economy, 31(1-2), 42-56.

Kalpana, W. (2017). Re-centring 'race' in development: Population policies and global capital accumulation in the era of the SDGs. Globalization, 14(3), 432-449.

Kothari, U. (2006a). An agenda for thinking about 'race' in development. Progress in Development, 6(1), 9-23.

Kothari, U. (2006b). Critiquing 'race' and racism in development discourse and practice. Progress in Development Studies, 6(1), 1-7.

Lorentzen, J. (2011). Food on the table and disease at the door: Insights for measuring innovation, In L. L. Ndabeni, C. M. Rogerson. \& M, Booyens. Innovation and Local Economic Development Policy in the Global South: New South African perspectives. Local Economy, 31(1-2), 299-311.

Mohammed, H. (2006). District and metro IDPs: a framework for contextualising and applying the NSDP, In C. M. Rogerson, Consolidating Local Economic Development in Post-Apartheid South Africa. Urban Forum, 19(3), 307-328.

Magubane, B. (1972). The South African problem as a view of imperialism, Journals of Black Studies, 3(1), 7593.

Marais, L. (2016). Local economic development beyond the centre: Reflections on South Africa's secondary cities. Local Economy, 31(1), 68-82.

Matjila, T. (2010). Tripartite alliance is dead. News 24, 23 August 2010.

Mbatha, A. (2014). SA poverty rate drops as government expands welfare programmes. Mail and Guardian, 3 April 2014.

Mbeba, R. D. (2014). Local economic development and urban poverty alleviation: The case of Buffalo City Metropolitan Municipality. Mediterranean Journal of Social Sciences, 5(20), 347-357.

Mayekiso. M., Miller, D. \& Swilling, M. (2000). A strategy for the development of urban underdevelopment, In P. Bond, Cities of gold, townships of coal: Essays on South Africa's new urban crisis, Trenton: Africa World Press, 331-341.

Mbeki, T. (1998). Address at the opening of the debate on 'reconciliation and nation building' in the National Assembly in May.

Monsson, C. K. (2014). Development without a metropolis: Inspiration for non-metropolitan support practice from Denmark. Local Economy, 29(4-5), 295-308.

Mqedlana, L. V. (2014). Contestation on the meanings of and their effect on interpretation of the notion of local economic development. MA Dissertation, University of the Witwatersrand, RSA.

Ndabeni, L. L., Rogerson, C. M. \& Booyens, M. (2016). Innovation and Local Economic Development Policy in the Global South: New South African perspectives. Local Economy, 31(1-2), 299-311.

Nel, E. (2001). Local economic development: A review and assessment of its current status in South Africa. Urban Studies, 38(1), 1003-102.

Nel, E. \& Binns, T. (2003). Putting 'development local government' into practice: The experience of South Africa's towns and cities. Urban Forum, 14(2-3), 165-183.

Nel, E. \& Rogerson, C. M. (2016). The contested trajectory of applied local economic development in South Africa. Local Economy, 31(1-2), 109-123.

Oranje, M., Van Huyssteen, E. \& Meiklejohn, C. (2009). National Spatial Development Perspective (NSDP) and assumptions on small-town economic investment by government. Johannesburg: Academy of Science of South Africa. 
Paton, C. (2014). Stats SA reports big drop in grinding poverty, Business Day, 4 April 2014.

Patterson, C. (2008). Country report: Local economic development in South Africa. Pretoria: German Agency for Development Cooperation (GTZ).

Pillay, D. (2006). COSATU, alliances and working-class politics, In S. Buhlungu, (ed.) Trade unions and democracy: Cosatu workers' political attitudes in South Africa. Pretoria: HSRC Press.

Pike, A., Rodriguez-Pose, R. \& Tomaney, J. (2016). Shifting horizons in local and regional development. Regional Studies, 1-13.

Plaatjie, S. R. (2013). Beyond western-centric and Eurocentric development: A case for decolonizing development. Africanus, 43(2), 118-130.

Plaatjie, S. R. (2014). Local economic development: A conceptual re-articulation. Journal of Economics and Behavioural Studies, 6(8), 616-624.

Pieterse, J. N. (2000). After post-development. Third World Quarterly, 21(2), 175-191.

Poplak, R. (2015). The long walk to the short walk: How the anti-corruption march is all about redemption.

Republic of South Africa. (1994). White Paper on Reconstruction and Development. Cape Town: RSA.

Republic of South Africa. (1996). The Constitution of the Republic of South Africa. Pretoria: Government Printers.

Republic of South Africa. (1998a). The Municipal Structures Act 117. Cape Town: RSA.

Republic of South Africa. (1998b). The White Paper on Local Development. Pretoria: Government Printers.

Republic of South Africa. (2000). The Municipal Systems Act 32. Cape Town: RSA

Republic of South Africa. (2009). Local government turnaround strategy: Working together, turning the tide in local government. Cape Town: RSA.

Rodriguez-Pose, A. \& Tijmstra, S. (2005). Sensitizing package on local economic development. Department of Geography and Environment. London: London School of Economics.

Rogerson, C. M. (2005). Local development planning in Ekurhuleni: emerging policy and strategy in South Africa's newest metropolitan area. Africa Insight, 34, 72-79.

Rogerson, C. M. (2008). Consolidating local economic development in post-apartheid South Africa, Urban Forum, 19(3), 307-328.

Statistics South Africa. (2014). Poverty trends in South Africa: An examination of absolute poverty between 2006 and 2011. Report no. 03-10-06. Pretoria: StatsSA.

Tabane, T. (2006). Reaping the whirlwind. Mail and Guardian online, 17 February 2006.

Tau, P. (2015). Police monitor Vuwani in Limpopo after municipal border protest turn violent. News 24, 31 August 2015.

Terblanche, S. (2002). A history of inequality in South Africa, 1652-2002. Durban: University of KwaZuluNatal Press.

Van Rooyen, C. (2012). Articulated transformations and accumulation by dispossession: Rand Water in South Africa. PhD Thesis, University of London, UK.

White, S. (2002). Thinking race, thinking development. Third World Quarterly, 23(3), 407-419.

Wray, C. (2015). An open data revolution for the Gauteng City Region? UrbanAfrica.net (African Center for Cities, Cape Town).

World Bank. (2016). Defining LED. 